\title{
ANALYSIS OF BOARD STRUCTURE,CORPORATE VALUE AND FINANCIAL POLICY
}

\author{
Yu-Chen Tu \\ Graduate Institute of Finance, Ming Chuan University, Taipei, Taiwan., yctu@ms5.hinet.net \\ Wei-Hung Lai \\ Graduate Institute of Management, Ming Chuan University, Taipei, Taiwan. \\ Heng-Chih Chou \\ Graduate Institute of Finance, Ming Chuan University, Taipei, Taiwan.
}

Follow this and additional works at: https://jmstt.ntou.edu.tw/journal

Part of the Business Commons

\section{Recommended Citation}

Tu, Yu-Chen; Lai, Wei-Hung; and Chou, Heng-Chih (2007) "ANALYSIS OF BOARD STRUCTURE,CORPORATE VALUE AND FINANCIAL POLICY," Journal of Marine Science and Technology. Vol. 15: Iss. 4, Article 4.

DOI: $10.51400 / 2709-6998.2046$

Available at: https://jmstt.ntou.edu.tw/journal/vol15/iss4/4

This Research Article is brought to you for free and open access by Journal of Marine Science and Technology. It has been accepted for inclusion in Journal of Marine Science and Technology by an authorized editor of Journal of Marine Science and Technology. 


\section{ANALYSIS OF BOARD STRUCTURE,CORPORATE VALUE AND FINANCIAL POLICY}

Acknowledgements

We are grateful to two anonymous reviewers for their valuable comments and suggestions. Errors remaining are definitely our responsibility. 


\title{
ANALYSIS OF BOARD STRUCTURE, CORPORATE VALUE AND FINANCIAL POLICY
}

\author{
Yu-Chen Tu*, Wei-Hung Lai**, and Heng-Chih Chou*
}

Key words: board structure, corporate value, financial policy, three-stage least squares (3SLS).

\begin{abstract}
The purpose of this paper is to examine how board structure relates to corporate value and financial policy of firms in Taiwan. Using quarterly data from ten stock-listed department stores in Taiwan during the period 2000-2005, this study builds a structural model with three equation sets, and then applies three-stage least squares (3SLS) to estimate all equations in the model simultaneously. It should be emphasized that all empirical deviations of normal asymptotic properties caused by OLS or 2 SLS in the previous studies can be improved by 3 SLS, even though the model of this study contains lagged endogenous variables. The empirical results finally show that most factors of board structure affect significantly corporate value and financial policy in the current period, except for the factor of Internal Board Shareholding Ratio with the significant effects in a time lag of one quarter.
\end{abstract}

\section{INTRODUCTION}

In recent years, corporate governance has become one of the dominant fields of finance and accounting. Shleifer and Vishny [32] defined that corporate governance is a system which ensures the investors including insiders and outsiders of the company to gain the normal returns. In other words, corporate governance acts as a mechanism to assure the deserved returns of shareholders and bondholders, and to prevent the internal directors, such as managers and controlling shareholders, from picking or wasting resources of the company. This mechanism can be used to solve the agency problems generated by the separation of ownership and management.

In fact, the study on the conflicts caused by the separation of ownership and management in the limited liability companies has a long history. Berle and Means

Paper Submitted 10/17/06, Accepted 12/14/06. Author for Correspondence: Yu-Chen Tu. E-mail: yctu@ms5.hinet.net

* Graduate Institute of Finance, Ming Chuan University, Taipei, Taiwan.

**Graduate Institute of Management, Ming Chuan University, Taipei, Taiwan.
[5] initially pointed out that if the managers pursue selfbenefits blindly, the company polices made by the managers may depart from the goal of maximizing the shareholders' equity. That was where the principalagent problem originated. Jensen and Meckling [17] showed that the separation of the ownership and management may generate agency costs. After that, a lot of external (Fama [11]) and internal (Williamson [34]) mechanisms are proposed by the scholars to reduce the agency costs. One of the internal mechanisms, the establishment of the board of directors represents the shareholders to reduce and control the agency costs, and also takes part in the operation to reduce the monitoring costs. Theoretically, the board of the directors may solve the principal-agent problem. However, the actual situation has many limitations. For example, the board of the directors needs vital and correct operational and financial information that is updated in real time to monitor and evaluate the performance of the company effectively. However, compared with the management teams including the general manager, the board of the directors is weak to receive the volume of information, and to have the capability of professional supervision and evaluation. This is going to diminish the management functions of the board of the directors.

As a result, attentions are paid to the relationship between the characteristics of the board of the directors and the operating performance. The characteristics of the board were discussed in the literatures include board size $[6,15]$, general manager occupied by the board chairman or his/her immediate relative [20, 29], the ratio of shareholding by the board [1,16], the ratio of members or Shareholding by external directors $[4,30]$, the ratio of members or Shareholding by internal directors $[25,31]$, the ratio of the pledged shares by the board [24], and so on.

In the meantime, there were a lot of financial studies focused on the relationship between the financial policies and operating performance. The mainstream of research also triggers the studies on the relationship between the characteristics of the board and financial policies, because the financial policies are made by the board of the directors. For example, 
Agrawal and Mandelker [2] and La Poarta et al. [22] studied the impact of the ownership structure reform on investment policy; Friend and Lang [13] and Kigeja [21] discussed the relationship between the ratio of shareholding by the board and financing policy; Jensen et al. [16] and Clasessens et al. [8] focused on the relationship between the ownership structure and dividend policy.

Summing up the prior literatures, we find that the same characteristic of the board in the studies often has different impacts on the operating performance and financial policies, because the different degree of the protection provided by different country laws to the external investors, or because the different ownership structures of the different sample companies [22]. Furthermore, most of the literatures covered only the bilateral relationships between the characteristics of the board and operating performance, the characteristics of the board and financial policies, or financial policies and operating performance. Few of literatures care about the trilateral relationships among the three topics, because the interactions among the three topics are really complicated. It's impossible to explain their trilateral relationship by a single formula.

There are some literatures in Taiwan (eg. Tu et al. [33]) used to study the trilateral relationships among the characteristics of the board, operating performance, and financial polices of Taiwan's listed companies by simultaneous equations. However, the environment of corporate governance for the stock-listed companies in Taiwan has changed a lot since the publication of Practical Regulations of Corporate Governance for StockListed Company stipulated by Taiwan Stock Exchange Corporation in October, 2002. In other words, a lot of laws and regulations for standardizing the corporate governance and protecting the external investors become available in Taiwan now, and the trilateral relationships among the characteristics of the board, operating performance, and financial polices may be different from those showed by Tu et al. [33]. Therefore, it is necessary to re-discuss the trilateral relationship of the three topics.

In addition, the ultimate goal of the corporate governance is not only to increase the operating performance by reducing agency costs, but also to maximize the equity of the investors, in other words, to increase the value of a firm. In this study, we therefore abandon the operating performance which is used in the previous literatures and adopt the corporate value instead. As a result, the purpose of this study is to examine the trilateral relationships among the board structure, financial policies, and corporate value.

The empirical samples used in this study are stocklisted firms of the industry of trade and department stores in Taiwan. As we know, Taiwan is an island nation bordering the sea, utilizing the sea for international trade, and developing a kind of marine market which causes people to develop a consumption style of multinational products. This kind of consumption style is easy to display in the exhibition of goods in the department stores. In other words, finding out the operation of the department stores could understand most parts of the present economy in Taiwan. Therefore, the empirical results of this study examining the impacts of the board structure on corporate value and financial policies in the trade and department stores industry will provide the decision makers and investors with the representative practical results in Taiwan.

\section{RESEARCH METHODOLOGY}

\section{Empirical steps}

The aim of this study is to find out the trilateral relationships among the board structure, financial policies, and corporate value. As stated by Barnhart and Rosenstein [4], there aren't any formal or precise structural equations available for the trilateral relationships today. Usually, we may adopt two approaches to estimate the structural equations, namely, single-equation method and system method. In the single-equation method, we estimate each equation in the system individually taking into account any restrictions placed on that equation without worrying about the restrictions on the other equations in the system. Since single-equation method only utilizes the variables appeared in the equation, and ignores the limitations of the other equations and the correlations of stochastic disturbance terms among different equations, it is called limited information method. In the system method, on the other hand, we estimate all the equations in the model simultaneously, taking due account of all restrictions on such equations by the omission or absence some variables, hence the name full information method. In this study, we would establish the structural equations by a simultaneous-equation method to avoid empirical deviations caused by the information inadequacies of the singleequation method.

Traditionally, the method of Ordinary Least Squares (OLS) is commonly used to estimate the model of simultaneous equations. However, the OLS is only good for exactly or just identified equations, and each equation should be estimated individually under its own restrictions. Because of the interdependence between the stochastic disturbance and the endogenous explanatory variables, the estimators applied by the OLS are not only biased no matter how large the sample size, but also inconsistent. 
Some subsequent studies try to use the method of Two-Stage Least Squares (2SLS) to amend the shortage of the OLS. Not only the 2SLS adapts to the overidentified equations and provides only one estimate per parameter, but also the 2SLS estimators are unbiased and consistent. Nevertheless, the sampling distribution of 2SLS coefficient estimators still can't satisfy the requirement of asymptotic property, such as approximate normality, even in the large-sample analysis, because the lagged endogenous variables will be contained in the equation system of this study and the mean square of the values can't converge in probability to a positive limit.

The method of Three-Stage Least Squares (3SLS) proposed by Zellner and Theill [36] can solve the problems of OLS and 2SLS. The 3SLS takes into account all restrictions on the equations in the system, and estimates all the equations simultaneously after getting rid of some variables by the stationary test on the data series. Compared with the OLS, the 3SLS pays more attentions to the correlations of stochastic disturbance terms of the cross-equations, and the estimators are unbiased and consistent. Meanwhile, the 3SLS is also preferable to the 2SLS in that the 3SLS considers more the stationary convergence of the mean square of the values taken by each lagged endogenous variables, and the estimators have the asymptotic efficiency.

The discussion of aforementioned three methods of the simultaneous-equation model is to achieve a more thorough examination of system sensitivity. Suitable empirical method is then efficiently performed on the system control. This study therefore would consist of the following three empirical steps.

Step 1: Take the Augmented Dickey-Fuller (ADF) Unit Root Test proposed by Dickey and Fuller [9] on the time-series data firstly. After the stationary of data series has been confirmed, we try to find out the best time lag of each variable by the Akaike Information Criterion (AIC) Rule and then check whether there is the Generalized Autoregressive Conditional Heterosce-dasticity (GARCH) phenomenon on the series.

Step 2: Select appropriate variables into each equation by the method of Stepwise Regression, and establish three equation sets of the simultaneous equation model. To assure the independence of all exogenous variables in each equation, the problem of multicollinearity will be examined by the method of Variance Inflation Factor (VIF).

Step 3: Estimate all equation in the model simultaneously by the method of 3SLS, and then analyze and discuss the empirical results.

\section{Statistic Methods}

\section{(1) ADF unit root test}

Granger and Newbold [14] showed that the regression analysis used by the OLS would produce the results of spurious regression if the time-series data of exogenous variables are non-stationary. Dickey and Fuller [9] proposed the method of ADF Unit Root Test can diagnose whether the time-series data are stationary. The main goal of the unit root test is to obtain an integrated order of the time-series data of variables so as to determine their characteristic of the stationary. When the test results show that the series is non-stationary if there is a unit root, a lagged first order difference should be applied in the series and the unit root test performed on it again till the time-series is stationary.

\section{(2) AIC rule}

To identify the time lag of the effects on financial policies or corporate value behind the reformation of board structure, it is necessary to select an optimum number of lag. Because the data for the variables in this study are quarterly, and because of Taiwan Company Law No. 195, Item 1 which stipulates: "the director cannot hold office for more than three years", the timeseries would be tested from one to twelve for the lag number by the method of AIC Rule. The formula of AIC is defined as $\operatorname{AIC}(p)=n \ln (\mathrm{SSE})+2 \mathrm{p}$, where $\mathrm{p}$ is the number of lag, $n$ is the number of observation, $\ln$ is Napierian logarithm, and SSE is the residual sum of square. In the twelve lags, the time lag with the smallest AIC is the optimum lag.

\section{(3) GARCH model}

Econometricians traditionally assumed that the possibility of disturbances in cross-section analyses is homoscedastic. Engle [10] suggested the possibility of heteroscedastic disturbances in cross-section analyses and autocorrelated disturbances in time series studies, and first proposed the method of Autoregressive Conditional Heteroscedasticity (ARCH) formulated that the recent disturbances influence the variance of the current disturbance. However, the estimation procedure under $\mathrm{ARCH}$ is very complicated and may have the risk of negative variances. A less restrictive specification of the disturbance equation amended by Bollerslev [7] is available in the formulation of Generalized Autoregressive Conditional Heteroscedasticity (GARCH). The known mode of $\operatorname{GARCH}(\mathrm{p}, \mathrm{q})$ expresses the conditional variance as a linear function of $p$ lagged squared disturbances and q lagged conditional variances. In practice 
the most frequent application is the $\operatorname{GARCH}(1,1)$. Testing the time-series data in this study for $\operatorname{GARCH}(1$, 1 ), we examine whether the assumption of conditional homoscedasticity is rejected if the coefficients of the equation are significantly different from zero.

\section{(4) Stepwise regression}

The stepwise regression can be applied from already-constructed equations by choosing independent variables that highly influence the behavior of the dependent variables, meanwhile rejecting the independent variables that have no significant effects on the dependent variables. This study uses the stepwise regression combining the forwards and backwards methods under the significance lever of $5 \%$. The choosing process should be repeated until no other variables can be selected and none eliminated. The stepwise regression is used to identify the significant variables of board structure, financial policy and corporate value.

\section{(5) VIF method}

In applying multiple regression analysis, independent variables should be mutually independent, and the influence of each independent variable on the dependent variables can be assessed. A strong linear relationship between independent variables would suggest that the two variables could be substituted for one another, and the variable with a low influence on the dependent variable could be eliminated.

To test multicollinearity of independent variables, this study uses the VIF method. In the VIF value test, $\mathrm{VIF}=\left(1-R_{i}^{2}\right)^{-1}$ represents the coefficient of determination in the regression for the ith independent variable towards all other independent variables. A coefficient greater than 10 indicates a strong presence of multicollinearity, and the variable can be eliminated [26].

(6) Three-stage least squares (3SLS)

In fact, Zellner and Theill [36] proposed the 3SLS method as an expansion of the 2SLS method. The computation steps in 3SLS are as follows: the first stage uses the OLS method to estimate the whole system formulated by the reduced-form equations; the second stage replaces the endogenously explanatory variables in the original (structural) equations by their estimated values from the first stage and then run the OLS again to obtain the estimated residuals; the third stage uses the estimated residuals to construct the covariance matrix of the structural equations and afterward applies the GLS (Generalized Least Squares) to estimate all struc- tural coefficients. The estimators thus have all the asymptotic properties.

\section{Empirical model design}

A simultaneous-equation model with board structure, financial policies, and corporate value is jointly determined within the model. The empirical model with three sets of equations can be expressed as:

$$
\left\{\begin{aligned}
\text { corporate value }= & \mathrm{f} \text { (board structure, financial } \\
& \text { policies }) \\
\text { financial policies } & =\mathrm{g} \text { (board structure, corporate } \\
& \text { value }) \\
\text { board structure }= & \mathrm{h} \text { (financial policies, corporate } \\
& \text { value })
\end{aligned}\right.
$$

\section{Data explanation, variable selection and definition}

\section{(1) Data and sources}

This study uses data from 2000 to 2005 that the time period of six years covered two board sessions and experienced approximately two stock price-index cycles in Taiwan. Totally twenty four quarterly data are collected and should be reliable.

Sample selections are based on the following rules: (1) the sample company should be a stock-listed company in the industry of trade and department store in Taiwan; (2) information of the sample company about the board structure, shareholding of directors and board, and financial statements should be completely available; (2) the sample company with mergers and acquisitions, bankruptcies, restructures, and changes of transaction method in stock market during the study period will not be included. Ten stock-listed companies are therefore selected, and their names and stock codes are as followings: Shin-Shin Department Store (2901), China Trust Department Store (2902), Far Eastern Department Stores (2903), Pan Overseas Corp. (2904), Mercuries and Associates (2905), Collins Group (2906), Test Rite International (2908), Tonlin Department Store (2910), Lesenphant Land (2911), President Chain Store (2912).

Information of their boards and financial data come from the published manuals, seasonal financial statements in the SFI library, and database of TEJ, etc.

\section{(2) Variables selection and definition}

It is noticeable that the absolute values of financial data in financial statements of the firms with different scales may be significantly different. However, Rees [28] stated that the objective of ratio analysis is to 
evaluate the effectiveness of the firm's policies, and that ratio analysis can help analysts to compare the relative performance of the firms with different scales in the industry. Therefore, this paper following most financial analysts applied financial ratios with relative values as the empirical variables to the cross-sectional analysis of different scaled firms within department stores industry.

Having compiled information from domestic and foreign literatures concerning the use of related variables, the study selected sixteen variables, which will be defined according to domestic conditions, as shown in Table 1 .

\section{EMPIRICAL RESULTS AND DISCUSSIONS}

\section{Test stationarity of time-series data}

To avoid producing the spurious empirical results, it is necessary to test whether the time-series data of variables are non-stationary before regression analysis. Among all of the sixteen variables discussed above in this study, fourteen of them should go through the unit root test except two dummy variables, BS and CEO. Let's take Shin-Shin Supermarket (2901) as an example. By Eview software, the ADF unit root test proposed by Dickey and Fuller [9] is applied, and the results of ADF test are shown in Table 2. Similar tests are carried out on other sample companies and won't be listed here.

\section{Selection of optimum lag}

Through the tests on the variables of each company based on AIC rules [3], we can find out their optimum lags. Since the sample companies are different from each other on their own specific business characteristics, same variable may have different optimum lag among the companies. Therefore, for the consistency of each variable among companies and the advantage of the upcoming analysis, the selection of the optimum lag for each variable would be based on the mode numbers of all companies. Table 3 listed the optimum lags for the variables of the sample companies.

From Table 3, we can find that the lags for the variables are a time lag ( $t-1)$ except the BS and EBS, which do not have any lag, among the factors of the board structure. In the financial policy factors, all of the variables do not have any lag except the DR, which has a time lag. Among the corporate value factors, all of the variables demonstrate a time lag except the PCFR, which does not have any lagged time.

Furthermore, we try to carry out GARCH tests on the time-series data of each variable of the sample companies by Lagrange Multiple Test method proposed by Engle [10]. Under a 5\% significance level, no GARCH phenomenon can be observed. This indicates that the variances are not conditionally heteroscedastic in the structural model and the regression analysis will only be based on the variables with the above optimum lags. As for the variables like BS and CEO, they will be put the original variables into the structural model directly since they are not time-series data.

\section{Stepwise regression and multicollinearity diagnosis}

In order to know the exact relationship among the board structure, financial policy, and corporate value of the stock-listed trade and department store companies in Taiwan, we adopt three sets of equations, sixteen in total, based on the empirical model for the three study issues. After finding out the optimum lags for variables, we then remove the variables that do not have significant effects on the independent variables of each equation through the Stepwise Regression. Stepwise regression is to try to find out the appropriate independent variables for the sixteen dependent variables that would be constructed the structural model of this study. Table 4 demonstrates the results of the stepwise regression. No significant independent variables can be found when ICR and PCFR act as dependent variables. As a result, the two equations are removed and there are fourteen multiple regression equations left.

Besides, the multicollinearity among the independent variables of each equation after Stepwise Regression is diagnosed by the method of Variance Inflation Factor (VIF). All VIF values of the fourteen equations tested by SAS statistics software are laid on the value of 1.0298 to 8.18821 , which is smaller than 10 . That is said, no multicollinearity can be found among the independent variables of each equation. Now, the structural model of variables among 14 multiple regression equations in three equation-sets are determined for 3SLS analysis.

\section{Empirical results of 3SLS and discussion}

\section{(1) The impacts of the board structure on the corporate value}

The 3SLS analysis is carried out by the method proposed by Zellner and Theill [36] through the command "proc syslin 3sls" of SAS statistics software to estimates all equations in the structural model simultaneously.

To understand the impacts of the board structure on the different factors of corporate value, in the equation set of the corporate value, only a single factor, such as PSR, PBR, or PER, of the corporate value is adopted as a dependent variable to form an equation. Together 
Table 1. The definition of variables used in this study

\begin{tabular}{|c|c|c|c|c|}
\hline \multicolumn{2}{|c|}{ Study issues } & Variable (Factor) & Definition and explanation & References \\
\hline \multirow{9}{*}{\multicolumn{2}{|c|}{ Board structure }} & Board size (BS) & $\begin{array}{l}\mathrm{BS}=1, \text { if number of directors is } \\
\text { between } 9 \text { and } 12 \text {; } \\
\mathrm{BS}=0, \text { if number of directors is } \\
\text { greater than } 12 \text { or less than } 9 .\end{array}$ & $\begin{array}{l}\text { Hiner [15], } \\
\text { Bhagat and Black [6] }\end{array}$ \\
\hline & & $\begin{array}{l}\text { Internal board size } \\
\text { (IBS) }\end{array}$ & $\begin{array}{l}\text { Number of internal directors } \div \\
\text { Total number of board members }\end{array}$ & $\begin{array}{l}\text { Patton and Baker [27], } \\
\text { Morck et al. [25] }\end{array}$ \\
\hline & & $\begin{array}{l}\text { External board size } \\
\text { (EBS) }\end{array}$ & $\begin{array}{l}\text { Number of external directors } \div \\
\text { Total number of board members }\end{array}$ & $\begin{array}{l}\text { Rosenstein and Wyatt [30], } \\
\text { Barnhart and Rosenstein [4] }\end{array}$ \\
\hline & & $\begin{array}{l}\text { Board shareholding } \\
\text { Ratio (BSR) }\end{array}$ & $\begin{array}{l}\text { Total shareholdings of board } \div \\
\text { Total outstanding shares }\end{array}$ & $\begin{array}{l}\text { Jensen } \text { et al. }[16] \text {, } \\
\text { Agrawal and Knoeber [1] }\end{array}$ \\
\hline & & $\begin{array}{l}\text { Internal board } \\
\text { shareholding ratio } \\
\text { (IBSR) }\end{array}$ & $\begin{array}{l}\text { Total shareholdings of internal } \\
\text { directors } \div \text { Total shareholdings of } \\
\text { board }\end{array}$ & Rosenstein and Wyatt [31] \\
\hline & & $\begin{array}{l}\text { External board } \\
\text { shareholding ratio } \\
\text { (EBSR ) }\end{array}$ & $\begin{array}{l}\text { Total shareholdings of external } \\
\text { directors } \div \text { Total shareholdings of } \\
\text { board }\end{array}$ & $\begin{array}{l}\text { Yermack [35], } \\
\text { Barnhart and Rosenstein [4] }\end{array}$ \\
\hline & & $\begin{array}{l}\text { Chief executive } \\
\text { officer (CEO ) }\end{array}$ & $\begin{array}{l}\text { Whether the CEO is occupied by the } \\
\text { board chairman or one of his/her } \\
\text { close relatives. }\end{array}$ & $\begin{array}{l}\text { Kesner and Dalton [19], } \\
\text { Rechner [29] }\end{array}$ \\
\hline & & & $\mathrm{CEO}=1$, if yes; $\mathrm{CEO}=0$, if not. & \\
\hline & & $\begin{array}{l}\text { Board pledged } \\
\text { shares ratio (BPSR) }\end{array}$ & $\begin{array}{l}\text { Total pledged shares of board } \div \\
\text { Total shareholdings of board }\end{array}$ & $\begin{array}{l}\text { Lee and Yeh [23], } \\
\text { Lee and Yeh [24] }\end{array}$ \\
\hline \multirow{5}{*}{$\begin{array}{l}\text { Financial } \\
\text { policy }\end{array}$} & \multirow[t]{2}{*}{$\begin{array}{l}\text { Invest- } \\
\text { ment } \\
\text { policy }\end{array}$} & $\begin{array}{l}\text { Capital spending } \\
\text { ratio (CSR) }\end{array}$ & $\begin{array}{l}\text { Capital spending } \div \text { Long term } \\
\text { capital }\end{array}$ & $\begin{array}{l}\text { Agrawal and Mandelker [2], } \\
\text { La Porta } \text { et al. [22] }\end{array}$ \\
\hline & & & $\begin{array}{l}\text { CRS is a proxy of CS. } \\
\text { And, } C S_{t}=F_{t}-F_{t-1}+D_{E P} \text {, } \\
\text { Where } C S_{t} \text { is the capital spending in } \\
\text { the period; } F A_{t} \text { is the fixed assets in } \\
\text { the period; } F A_{t-1} \text { is the fixed assets in } \\
\text { the previous period; } \mathrm{DEP}_{t} \text { is the } \\
\text { depreciation cost in the period. }\end{array}$ & \\
\hline & \multirow{2}{*}{$\begin{array}{l}\text { Financing } \\
\text { policy }\end{array}$} & Debt ratio (DR) & Long debt $\div$ Total asset & Friend and Lang [13] \\
\hline & & $\begin{array}{l}\text { Interest coverage } \\
\text { ratio (ICR) }\end{array}$ & EBIT $\div$ Interest expense & Kigeja [21] \\
\hline & $\begin{array}{l}\text { Dividend } \\
\text { policy }\end{array}$ & $\begin{array}{l}\text { Dividend payout } \\
\text { ratio (DPR) }\end{array}$ & $\begin{array}{l}\text { Cash dividend payout ratio }+ \text { Stock } \\
\text { dividend payout ratio }\end{array}$ & $\begin{array}{l}\text { Jensen et al. [16], } \\
\text { Claessens } \text { et al. [8] }\end{array}$ \\
\hline \multirow{4}{*}{\multicolumn{2}{|c|}{ Corporate value }} & $\begin{array}{l}\text { Price-sales ratio } \\
\text { (PSR) }\end{array}$ & $\begin{array}{l}\text { Market value of equity } \div \text { Total } \\
\text { revenue }\end{array}$ & $\begin{array}{l}\text { Fischer and Jordan [12], } \\
\text { Jones (2004) }\end{array}$ \\
\hline & & $\begin{array}{l}\text { Price-book value } \\
\text { ratio (PBR) }\end{array}$ & $\begin{array}{l}\text { Market value of equity } \div \text { Book } \\
\text { value of equity }\end{array}$ & $\begin{array}{l}\text { Fischer and Jordan [12], } \\
\text { Jones [18] }\end{array}$ \\
\hline & & $\begin{array}{l}\text { Price-earnings ratio } \\
\text { (PER) }\end{array}$ & Stock price $\div$ Earning per share & $\begin{array}{l}\text { Fischer and Jordan [12], } \\
\text { Jones [18] }\end{array}$ \\
\hline & & $\begin{array}{l}\text { Price-cash flow } \\
\text { ratio (PCFR) }\end{array}$ & $\begin{array}{l}\text { Market value of equity } \div \text { Net cash } \\
\text { flow }\end{array}$ & $\begin{array}{l}\text { Fischer and Jordan[12], } \\
\text { Jones [18] }\end{array}$ \\
\hline
\end{tabular}


Table 2. ADF test of the variables - Shin-Shin Supermarket (2901) as example

\begin{tabular}{|c|c|c|c|c|c|c|}
\hline Variables & $\mathrm{ADF}$ & $\begin{array}{c}5 \% \\
\text { Critical } \\
\text { Value }\end{array}$ & $\begin{array}{c}\text { The first order } \\
\text { difference is } \\
\text { need? }\end{array}$ & $\begin{array}{l}1 \text { diff } \\
\text { ADF }\end{array}$ & $\begin{array}{c}5 \% \\
\text { Critical } \\
\text { Value }\end{array}$ & Stationary? \\
\hline BS & NA & & & & & \\
\hline IBS & -1.6857 & -2.9981 & $\mathrm{Y}$ & -3.3272 & -3.0049 & Y \\
\hline EBS & -0.1603 & -2.9981 & $\mathrm{Y}$ & -4.3316 & -3.0049 & Y \\
\hline BSR & -2.7493 & -2.9981 & Y & -5.7485 & -3.0049 & Y \\
\hline IBSR & -3.0829 & -2.9981 & $\mathrm{~N}$ & & & \\
\hline EBSR & -2.1222 & -2.9981 & $\mathrm{Y}$ & -5.5427 & -3.0989 & Y \\
\hline CEO & NA & & & & & \\
\hline BPSR & -4.0723 & -3.0656 & $\mathrm{~N}$ & & & \\
\hline CSR & -5.2218 & -2.9981 & $\mathrm{~N}$ & & & \\
\hline DR & 4.3830 & -3.0810 & $\mathrm{~N}$ & & & \\
\hline ICR & -6.0542 & -2.9981 & $\mathrm{~N}$ & & & \\
\hline DPR & -2.0329 & -3.0810 & $\mathrm{~N}$ & & & \\
\hline PSR & -7.3719 & -2.9981 & $\mathrm{~N}$ & & & \\
\hline PBR & -9.8940 & -2.9981 & $\mathrm{~N}$ & & & \\
\hline PER & -4.2216 & -3.0049 & $\mathrm{~N}$ & & & \\
\hline PCFR & -4.6426 & -2.9981 & $\mathrm{~N}$ & & & \\
\hline
\end{tabular}

Notes: 1. NA represents that the data are not quantitative.

2. If $\mathrm{ADF}>5 \%$ critical value, the first order difference is required.

If $\mathrm{ADF}<5 \%$ critical value, the data are stationary.

Table 3. The optimum lags for sample companies' variables

\begin{tabular}{ccccccccccccccc}
\hline Company code & IBS & EBS & BSR & IBSR & EBSR & BPSR & CSR & DR & ICR & DPR & PSR & PBR & PER & PCFR \\
\hline 2901 & 1 & 1 & 1 & 1 & 1 & 1 & 0 & 5 & 0 & 0 & 1 & 5 & 2 & 0 \\
2902 & 0 & 0 & 5 & 5 & 1 & 4 & 0 & 1 & 0 & 0 & 1 & 5 & 0 & 5 \\
2903 & 0 & 0 & 1 & 3 & 2 & 0 & 0 & 3 & 1 & 0 & 5 & 1 & 0 & 0 \\
2904 & 1 & 1 & 1 & 1 & 1 & 3 & 1 & 1 & 0 & 0 & 4 & 1 & 0 & 0 \\
2905 & 1 & 0 & 1 & 1 & 1 & 1 & 0 & 0 & 1 & 0 & 1 & 3 & 2 & 4 \\
2906 & 2 & 1 & 2 & 0 & 1 & 5 & 0 & 5 & 4 & 4 & 0 & 1 & 4 & 0 \\
2908 & 0 & 0 & 3 & 3 & 0 & 4 & 1 & 0 & 0 & 5 & 2 & 0 & 1 & 0 \\
2910 & 0 & 1 & 1 & 1 & 1 & 4 & 0 & 1 & 5 & 0 & 1 & 1 & 1 & 0 \\
2911 & 0 & 0 & 2 & 1 & 1 & 1 & 0 & 1 & 0 & 0 & 5 & 0 & 1 & 0 \\
2912 & 2 & 5 & 1 & 1 & 1 & 0 & 5 & 2 & 1 & 4 & 1 & 1 & 1 & 0 \\
\hline Optimum lag & 0 & 0 & 1 & 1 & 1 & 1 & 0 & 1 & 0 & 0 & 1 & 1 & 1 & 0 \\
\hline
\end{tabular}

with the eight equations of the set for the board structure factor and three equations of the set for the financial policy factor, a simultaneous-equation model is established. In other words, the 3SLS analysis is based on twelve simultaneous multiple regression equations. As a result, one different corporate value factor is included in the model repeatedly for three times.

Table 5 shows the results of 3SLS analysis. We can find that factors of the board structure have nothing to do with PER, but are related to the PSR and PBR. Here are the findings in the empirical results: (a) BS: The PBR as a proxy variable for corporate value is negatively related to the BS in the period significantly. This is in accordance with the results of Hiner [15]. The overabundance of directors may generate cliques and can not reach the common consensus that lead to slow decision-making and inefficient performance. On the other hand, insufficient members of the board may bring arbitrary decisions, subjectivism and self-interest behaviors by controlling director. Therefore, either overabundant or insufficient board size is a significantly 
Table 4. Variables selected by stepwise regression

\begin{tabular}{|c|c|c|c|c|c|c|c|c|c|c|c|c|c|c|c|}
\hline $\begin{array}{l}\text { Dependent } \\
\text { variable } \\
\text { variable }\end{array}$ & BS & IBS & EBS & BSR & IBSR & EBSR & CEO & BPSR & CSR & DR & ICR & DPR & PSR & PBR I & PER PCFR \\
\hline BS & & & & & & & & & & & & & & $*$ & \\
\hline IBS & & & & & & & & & & $*$ & & & & * & \\
\hline EBS & & & & & & & & & & * & & & $*$ & * & \\
\hline BSR & & & & & & & & & * & & & & * & * & \\
\hline $\mathrm{BSR}_{\mathrm{t}-1}$ & & & & & & & & & & & & & $*$ & & \\
\hline IBSR & & & & & & & & & & * & & & * & $*$ & \\
\hline $\mathrm{IBSR}_{\mathrm{t}-1}$ & & & & & & & & & & & & & $*$ & & \\
\hline EBSR & & & & & & & & & $*$ & * & & & & * & \\
\hline $\mathrm{EBSR}_{\mathrm{t}-1}$ & & & & & & & & & & & & & & & \\
\hline CEO & & & & & & & & & & $*$ & & * & & & \\
\hline BPSR & & & & & & & & & & & & & & * & \\
\hline $\mathrm{BPSR}_{\mathrm{t}-1}$ & & & & & & & & & * & & & & & & \\
\hline CSR & & & & & $*$ & & & & & & & & * & * & \\
\hline DR & * & * & * & & $*$ & & * & * & & & & & $*$ & $*$ & * \\
\hline $\mathrm{DR}_{\mathrm{t}-1}$ & & & & & $*$ & * & & $*$ & & & & & & & \\
\hline ICR & & & & & & & & & & & & & & $*$ & \\
\hline DPR & & & & & & & * & & & & & & * & & $*$ \\
\hline PSR & & $*$ & $*$ & $*$ & * & * & $*$ & & & * & & & & & \\
\hline $\mathrm{PSR}_{\mathrm{t}-1}$ & & & & $*$ & $*$ & & $*$ & & & $*$ & & & & & \\
\hline PBR & $*$ & & * & $*$ & & & $*$ & * & & & & & & & \\
\hline $\mathrm{PBR}_{\mathrm{t}-1}$ & $*$ & * & & & & * & & & * & & & & & & \\
\hline PER & & & & & * & & & & & * & & * & & & \\
\hline $\mathrm{PER}_{\mathrm{t}-1}$ & & & & $*$ & $*$ & & & & & $*$ & & & & & \\
\hline PCFR & $*$ & & & & & & & & & & & & & & \\
\hline
\end{tabular}

Notes: * represents the independent variables should be selected into the corresponding regression equations.

Table 5. The 3SLS analysis of the board structure on corporate value

\begin{tabular}{lccc}
\hline Variable Main equation & PSR & PBR & PER \\
\hline $\mathrm{R}^{2}$ & 0.59321 & 0.66338 & 0.09738 \\
Intercept & 1.116142 & 648.7117 & 27.83983 \\
BS & & $-523.339(-9.48)^{* * *}$ & \\
IBS & & $-391.961(-2.62)^{* * *}$ & \\
EBS & $-1.11569(-1.48)$ & $-13.0794(-2.66)^{* * *}$ & \\
BSR & $-0.09058(-2.59)$ & $39.95370(10.07)^{* * *}$ & \\
BSR $_{\mathrm{t}-1}$ & $0.068545(2.00)$ & & \\
IBSR & $0.23892(-8.34)^{* * *}$ & $15.50148(-6.76)^{* * * *}$ & \\
IBSR & & & \\
EBSR & $-0.360507(12.12)^{* * *}$ & $-53.3082(-8.51)^{* * *}$ & \\
BPSR & & $-0.695833(-2.84)^{* * *}$ & \\
CSR & $0.15456(2.99)^{* * *}$ & $13.65113(1.69)$ & $-134.339(-2.09)$ \\
DR & $-2.98735(-3.18)^{* * *}$ & $-738.679(-4.74)^{* * *}$ & \\
ICR & & $-0.00215(-1.21)$ & $46.97407(2.96)^{* * *}$ \\
DPR & $-0.29825(-1.64)$ & & \\
\hline
\end{tabular}

Notes: 1 . The values in the table are coefficients, and (.) are the t-values.

2. *** is significantly under the level of $1 \%$. 
negative impact on corporate value.

(b) IBS: The PBR as a proxy variable for corporate value is also negatively related to the IBS in the period significantly. The empirical result is the same as that of Morck et al. [25]. When the internal board size is increasing, the independence of the board will be hurt, which brings significantly negative impacts on the corporate value.

(c) EBS: The relationship between EBS and PSR or PBR as a proxy variable for corporate value is negative in the period, but only EBS and PBR significantly. In most prior literatures, external directors are found to have more efficiency in supervision and increasing company performance. However, in this study, we find that the election of external directors of stock-listed trade and department store companies in Taiwan are greatly supported by internal managers. They therefore can not supervise the company behaviors effectively or keep an independent and transcendent position. Thus, the external board size has significantly negative impacts on the corporate value.

(d) BSR: The BSR has negative impacts on the PSR as a proxy for corporate value in the period, but not significantly. However, the relationship between BSR and PBR as a proxy for corporate value is significantly positive in the current period that matches the findings of Tu et al. [33]. When the board shareholding ratio is high, the self-interests of the board tend to be consistent with the company's benefits. The board is more willing to monitor the operation of company and has a positive impact on the corporate value. Furthermore, the one time lag BSR is positively related to the PSR, but not significantly.

(e) IBSR: In the current period the IBSR is significantly positively related to the PSR and PBR. However, the one time lag IBSR has a significantly negative relationship to the PSR. It is the possible reason that the higher the internal board shareholding ratio in the current period, the more attentions by the directors will be paid to the operation and administration of the company. As a result, it's good for the current pricesales ratio and price-book ratio as the proxy variables of corporate value. However, one quarter later, the price-sales ratio may decline because of the growth of sales caused by good operation, or the drop of stock price caused by the internal centralization of the shares.

(f) EBSR: The EBSR has a significantly negative impact on the PBR that accords with the showings of Yermack [35]. The possible reason is that the higher the external board shareholding ratio is, the more conservative the decision-making of the company will be. This may significantly harm the corporate value.

(g) CEO: The CEO has nothing to do with the corporate value.

(h) BPSR: The relationship between BPSR and PBR is significantly negative. Possibly, it is the reason that the higher the board pledged shares ratio, the deeper the degree of participation in stock markets the board is thought to be. The board's intervention in the stock market has a significantly negative impact on the corporate value.

\section{(2) The impacts of the board structure on the financial policies}

Similarly, to understand the impacts of the board structure on the different factors of financial policy, in the equation set of financial policy factors, only a single factor (such as CSR, DR, or DPR) is adopted as the dependent variable to construct an equation. Combining with eight equations in the set of the board structure factors, and three equations in the set of corporate value factors, we establish a simultaneous-equation model. In other words, twelve multiple regression equations with one different factor of corporate value are used to carry out 3SLS analysis repeatedly for three times.

The results of 3SLS are listed in Table 6, and the analysis and discussions of the results as follows.

(a) The impact of the board structure on the investment policy.

(1) BSR: The relationship between BSR and CSR as a proxy for investment policy is significantly negative. It is that the higher the board shareholding ratio in the current period, the less the capital spending ratio of the investment will be observed in the short term. This result supports the conclusion by La Porta et al. [22]: the reform of board ownership structure would significantly affect the investment policy of the company.

(2) EBSR: The EBSR has a significantly positive relationship with CSR. The reason is that the external directors prefer the diversified investment to lower the operational risk they may face, and therefore tend to adopt an expanding attitude to enlarge the capital spending ratio in the investment.

(3) BPSR: The one time lag BPSR is positively related to the CSR, but not significantly.

(b) The impact of the board structure on the financing policy.

(1) IBS and IBSR: The DR as a proxy variable for financing policy is significantly negatively affected by both of the IBS and IBSR. The result shows that the higher the internal board size or the internal board shareholding ratio is, the less the debt ratio of financing 
Table 6. The 3SLS analysis of the board structure on financial policies

\begin{tabular}{lccc}
\hline \multicolumn{1}{c}{ Main equation } & $\begin{array}{c}\text { Investment } \\
\text { policy }\end{array}$ & $\begin{array}{c}\text { Financing } \\
\text { policy }\end{array}$ & $\begin{array}{c}\text { Dividend } \\
\text { policy }\end{array}$ \\
\cline { 2 - 4 } Variable & CSR & DR & DPR \\
\hline $\mathrm{R}^{2}$ & 0.08598 & 0.49396 & 0.04340 \\
Intercept & 0.278826 & 0.91276 & 0.183042 \\
IBS & & $-0.1051(-6.07)^{* * *}$ & \\
EBS & $-0.15452(-4.63)^{* * *}$ & $0.19184(-3.82)^{* * *}$ & \\
BSR & & & \\
IBSR & $0.198473(4.18)^{* * *}$ & $-0.008946(10.00)^{* * *}$ & \\
EBSR & & $0.00571(-4.19)^{* * *}$ & $-0.14276(-1.51)$ \\
CEO & $0.004063(1.80)$ & $0.155830(7.60)^{* * *}$ & \\
BPSR & & $-0.01024(-3.06)^{* * *}$ & \\
PSR & & $-0.00727(-2.17)$ & \\
PSR $_{\mathrm{t}-1}$ & & & \\
PBR $_{\mathrm{t}-1}$ & $0.000902(2.26)$ & $-0.00008(-1.74)$ & $0.000697(2.81)^{* * * *}$ \\
PER $_{\text {PER }_{\mathrm{t}-1}}$ & & $-0.00014(-2.79)^{* * *}$ & \\
\hline
\end{tabular}

Notes: 1 . The values in the table are coefficients, and (.) are the $t$-values.

2. *** is significantly under the level of $1 \%$.

to lower the financial risk and to protect self-interests of internal directors will be.

(2) EBS and EBSR: Both of the EBS and EBSR are significantly positively related to the DR. We find that most of the external directors in the stock-listed trade and department store companies in Taiwan are occupied by accounting or financial institutions. As a result, when the external board size or the external board shareholding ratio is higher, the company will more likely increase the debt ratio by financing expansion assisted by the external directors.

(3) CEO: The CEO has significantly positive impacts on the DR. If the chief executive officer is occupied by the board chairman or his/her close relatives, the family should hold a fairly amount of shares of the company. In order to keep controlling the company, the company tends to run into debt instead of issuing new shares to collect required capitals. Therefore, the financing policy of the company would be expansive.

(c) The impacts of the board structure on the dividend policy.

There is a negative relationship between DPR and CEO of the factors of board structure only, but not significantly.

\section{(3) Summary of the empirical results}

Table 7 listed the summary of the complete empiri- cal results. Except for IBSR, which has a lagged significant impact on the corporate value, all the other factors of the board structure affect significantly corporate value and financial policy in the current period.

\section{CONCLUSIONS AND RECOMMENDATIONS}

\section{Conclusions}

In this study, we try to examine the impacts of the board structure on corporate value and financial policy. Based on the data of ten stock-listed trade and department store companies in Taiwan during 2000 to 2005 as empirical samples, we construct a structural simultaneous-equation model with three equation sets that represent the board structure factors, the corporate value factors, and the financial policy factors to avoid the deviation of results caused by the single-equation method.

Since most variables of this study are time-series data, we firstly confirm the stationarity of data by ADF unit root test. The optimum lags are then determined by the AIC rule, and tested whether there is the GARCH phenomenon on the series. To identify the structural model for the coming 3SLS analysis, appropriate variables are selected from each equation by Stepwise Regression, and the multicollinearity of independent variables is also examined by the VIF method. At last, the simultaneous-equations model is applied by the 3SLS method to find out the impacts of the board 
Table 7. The summary of the empirical results

\begin{tabular}{lcccc}
\hline Board & Corporate & & Financial policies & \\
\cline { 2 - 4 } Structure & value & Investment policy & Financing policy & Dividend policy \\
\hline BS & - & & - & \\
IBS & - & & + \\
EBS & - & - & - \\
BSR & + & & \\
IBSR & + & + & + \\
IBSR & - & & + \\
EBSR & - & & \\
CEO & - & & & \\
BPSR & - & & & \\
\hline
\end{tabular}

Notes: "+" is a significantly positive, and "-" is a negative one.

structure on corporate value and financial policies. It should be emphasized that all the biased, inconsistent, and non-normal asymptotic properties caused by the OLS or 2SLS in the previous studies can be improved by the 3SLS in this study. The 3SLS is thought to be a more sophisticated and advanced statistics method that can achieve a more thorough examination of system sensitivity.

The empirical results of this study show: (1) on the corporate value, the BS, IBS, EBS, EBSR, and BPSR have significantly negative effects, but the BSR and IBSR have significantly positive impacts; (2) on the investment policy, the BSR has a significantly negative impact, but the EBSR has a significant positive one; (3) on the financing policy, the IBS and IBSR have significantly negative impacts, but the EBS, EBSR, CEO have significantly positive ones; (4) on the dividend policy, none of the board structure factors has any significant effect; (5) most of the board structure factors have immediate and significant impacts on the corporate value, financial policies in the current period, except for the IBSR with a significant impact a time lag of one quarter.

\section{Limitations and recommendations for future study}

Although this study using a more scientific method than before has completed an empirical and appropriable research on the stock-listed trade and department store companies in Taiwan, there are still some research limitations that could be clarified and overcame for future study. These are as follows:

(a) Board members within the firm in Taiwan often perform actions in others' names or in the style of holding companies to hide their shares. The validity of empirical results would therefore be questionable if the empirical data are very different from the reality.

(b) This study ruled out the sample company with mergers and acquisitions, bankruptcies, restructures, and changes of transaction method in stock market. It would be the possible results of the selection bias among the samples.

(c) Some variables such as firm's scale and age would have different potential impacts of the board structure on corporate value and financial policy among the different firms. It is the suggestion that future study could take further procedures to control these effects and the empirical results would be more accurate and reliable.

\section{ACKNOWLEDGEMENTS}

We are grateful to two anonymous reviewers for their valuable comments and suggestions. Errors remaining are definitely our responsibility.

\section{REFERENCES}

1. Agrawal, A. and Knoeber, C.R., "Firm Performace and Mechanisms to Control Agency Problems between Managers and Shareholder," Journal of Financial and Quantitative Analysis, Vol. 31, pp. 337-398 (1996).

2. Agrawal, A. and Mandelker, G.N., "Managerial Incentive and Corporate Investment and Financial Decision," Journal of Finance, Vol. 42, pp. 823-837 (1987).

3. Akaike, H., "Information Theory and an Extension of Maximum Likelihood Principle," In Petrov, B. and Csake, F. (Eds), Second International Symposium on Information Theory, Akademiai Kiado, Budapest, Hungary (1973).

4. Barnhart, S.W. and Rosenstein, S., "Board Composition, Managerial Ownership, and Firm Performance: An Empirical Analysis," The Financial Review, Vol. 33, pp. 
1-16 (1998).

5. Berle, A.A. and Means, G.C., The Modern Corporation and Property, Macmillan, NY (1932).

6. Bhagat, S. and Black, B., "Board Independence and Long Term Firm Performance," University of Colorado, Working Paper (2000).

7. Bollerslev, T., "Generalized Autoregressive Conditional Heteroscedasticity," Journal of Econometrics, Vol. 31, pp. 307-327 (1986).

8. Claessens, S., Djankov, S., and Lang, L.H.P., "The Separation of Ownership and Control in East Asian Corporations," Journal of Financial Economics, Vol. 58, pp. 81-112 (2000).

9. Dickey, D. and Fuller, W., "Likelihood Ratio Statistics for Autoregressive Time Series with a Unit Root," Econometrica, Vol. 49, pp. 1057-1072 (1981).

10. Engle, R., “Autoregressive Conditional Heteroscedasticity with Estimates of the Variance of United Kingdom Inflations," Econometrica, Vol. 50, pp. 987-1008 (1982)

11. Fama, E.F., "Agency Problems and the Theory of the Firm," Journal of Political Economy, Vol. 88, pp. 288307 (1980).

12. Fischer, D.E. and Jordan, R.J., Security Analysis and Portfolio Management, Prentice Hall, NJ (1995).

13. Friend, I. and Lang, L.H.P., "An Empirical Test of the Impact of Managerial Self-Interest on Corporate Capital Structure," Journal of Finance, Vol. 43, pp. 271-281 (1988).

14. Granger, C.W.J. and Newbold, P., "Spurious Regressions in Econometrics," Journal of Econometrics, Vol. 2, pp. 111-20 (1974).

15. Hiner, O.S., "The Size of Company Boards," Management International Review, Vol. 17, pp. 68-81 (1967).

16. Jensen, G.R., Solberg, D.P., and Zorn, T.S., "Simultaneous Determination of Insider Ownership, Debt, and Dividend Policies," Journal of Financial and Quantitative Analysis, Vol. 27, pp. 247-262 (1992).

17. Jensen, M. and Meckling, W.H., "Theory of the Firm and Managerial Behavior, Agency Costs, and Ownership Structure," Journal of Economics, Vol. 3, pp. 305-360 (1976).

18. Jones, C.P., Investment: Analysis and Management, John Wiley \& Sons, Singapore (2004).

19. Kesner, I.F. and Dalton, D.R., "Composition and CEO Duality in Boards of Directors: An International Perspective," Journal of International Business Studies, Vol. 18, pp. 33-42 (1987).

20. Kesner, I.F. and Johnson, R.B., "An Investigation of the Relationship between Board Composition and Stockholder Suits," Strategic Management Journal, Vol. 11,
No. 4, pp. 327-336 (1990).

21. Kigeja, S., "Agency Theory Problems and Their Catalytic Impact on the Formulation of an Organization's Financial Management Financing Policies," UMI (1989).

22. La Porta, R., Lopez-de-Silanes, F., Shleifer, A., and Vishny, R., "Investor Protection and Corporate Governance," Journal of Financial Economics, Vol. 58, pp. 3-27 (2000).

23. Lee, T.S. and Yeh, Y.H., "Corporate Governance and Financial Distress," The $8^{\text {th }}$ APFA Finance Conference, Bangkok, Thailand (2001).

24. Lee, T.S. and Yeh, Y.H., "Taiwan Research of Corporate Governance," Asian Corporate Governance Network 2002, Hitostubashi University, Tokyo, Japan (2002).

25. Morck, R., Shleifer, A., and Vishny, R.W., "Management Ownership and Market Valuation: An Empirical Analysis," Journal of Financial Economics, Vol. 20, pp. 293-315 (1988).

26. Neter, J., Wasserman, W., and Kunter, M.H., Applied Linear Statistical Models, Richard D. Irwin, Inc., Homewood, IL (1990)

27. Patton, A. and Baker, J.C., "Why Won't Directors Rock the Boat?" Harvard Business Review, Vol. 65, pp. 10-18 (1987).

28. Rees, B., Financial Analysis, Prentice-Hall Europe, London, UK (1995).

29. Rechner, P.L., "Corporate Governance: Fact or Fiction?” Business Harizons, Vol. 4, pp. 11-15 (1989).

30. Rosenstein, S. and Wyatt, J.G., "Outside Directors, Board Independence, and Shareholder Wealth," Journal of Financial Economics, Vol. 26, pp. 175-191 (1990).

31. Rosenstein, S. and Wyatt, J.G., "Inside Directors, Board Effectiveness, and Shareholder Wealth," Journal of Financial Economics, Vol. 44, pp. 229-250 (1997).

32. Shleifer, A. and Vishny, R., "A Survey of Corporate Governance," Journal of Finance, Vol. 52, No. 2, pp. 117-142 (1997).

33. Tu, Y.C., Huang, C., and Lin, J.C., "Board Structure, Firm Performance and Financial Policy: Empirical Analysis of Stock-Listed Firms in Taiwan," Journal of Management \& Systems, Vol. 9, No. 3, pp. 345-368 (2002).

34. Williamson, O.E., "Organization Form, Residual Claimants, and Corporate Control," Journal of Law and Economics, Vol. 26, pp. 351-366 (1983).

35. Yermack, D., "Higher Market Valuation of Companies with a Small Board of Directors," Journal of Financial Economics, Vol. 40, pp. 185-211 (1996).

36. Zellner, A. and Theil, H., "Three Stage Least Squares: Simultaneous Estimation of Simultaneous Equations," Econometrica, Vol. 30, pp. 63-68 (1962). 